EDITED BY

Jeremy MacClancy

\title{
Alternative countrysides
}

Anthropological approaches to rural Western Europe today 
Alternative countrysides

\section{MANCHESTER 1824}

Manchester University Press 
Blank page 


\title{
Alternative countrysides \\ Anthropological approaches to rural Western Europe today
}

\author{
EDITED BY JEREMY MACCLANCY
}

Manchester University Press 
Copyright $(C$ Manchester University Press 2015

While copyright in the volume as a whole is vested in Manchester University Press, copyright in individual chapters belongs to their respective authors.

This electronic version has been made freely available under a Creative Commons (CC-BYNC-ND) licence, thanks to the support of Knowledge Unlatched, which permits noncommercial use, distribution and reproduction provided the author(s) and Manchester University Press are fully cited and no modifications or adaptations are made. Details of the licence can be viewed at https://creativecommons.org/licenses/by-nc-nd/3.0/

Published by Manchester University Press

Altrincham Street, Manchester M1 7JA

www.manchesteruniversitypress.co.uk

British Library Cataloguing-in-Publication Data

A catalogue record for this book is available from the British Library

Library of Congress Cataloging-in-Publication Data applied for

ISBN 9780719096846 hardback

First published 2015

The publisher has no responsibility for the persistence or accuracy of URLs for any external or third-party internet websites referred to in this book, and does not guarantee that any content on such websites is, or will remain, accurate or appropriate.

Typeset by Out of House Publishing 